\title{
Groundwater Resource Assessment: in the Context of Bhawaniganj Pourashava
}

\author{
A. B. M. I. Hossain ${ }^{1}$, R. M. Chowdhury ${ }^{1}$ and F. Afifah ${ }^{2}$ \\ ${ }^{1}$ Junior Engineer, Institute of Water Modelling, Dhaka-1206, Bangladesh, \\ ${ }^{1}$ Assistant Professor, Department of Civil Engineering, University of Asia Pacific, Dhaka-1205, Bangladesh ${ }^{2}$ \\ Student, Department of Civil Engineering, Bangladesh University of Engineering and Technology, Dhaka-1000, \\ Bangladesh,
}

\begin{abstract}
Groundwater $(G W)$ is the major source of irrigation in Barind Tract, largest Pleistocene physiographic unit of the Bengal Basin, recognized as a unit of Old Alluvium. Due to overexploitation of this priceless natural resource and lowest amount of rainfall occur in this region, the obtainability of GW resource is under threaten. In spite of these devastating effects there is no sufficient plan of action for protecting this resource from overexploitation. This study describes a contemporary methodology for assessment of available GW resources in Bhawaniganj Pourashava of Bangladesh. Based on the available borelogs, the probability lithological log demonstrates that top most layer is heavy clay layer, which is followed by aquifer layers alternatively arranged within different depths separated by clay (aquitard and aquiclude layer). However, development of numerical $G W$ modelling as well as simulation of $G W$ flow has been performed in an integrated MIKE-11 and MIKE-SHE platform. Based on the simulation and water level fluctuation analysis, availability of $G W$ resource has been assessed for the design year. In selecting design year, most weight has been considered for $80 \%$ dependable of annual rainfall, because this is considered most generally significant for domestic requirement considerations. The design year (2008 in this study) is selected based on the return period analysis of rainfall from the precipitation records for a period of 30 years spanning over 1980 to 2009 obtained from 18 rain gauge stations located in and around the model area. From this assessment it is found that the allowable limit of abstraction for the Bhawaniganj Pourashava at lower shallow aquifer is found to be $4.19 \mathrm{Mm} 3 \mathrm{per}$ annum which is higher than the required water demand of $1.60 \mathrm{Mm} 3$ for the year 2040.
\end{abstract}

Keywords: Barind Tract; MIKE-11; MIKE-SHE; Lithology; Design year

\section{Introduction}

Due to ample availability in nature and natural conservation from contamination, groundwater (GW) is usually the major source of potable water supply in most of the developing countries in the world. Globally, irrigation activities and industrial as well as domestic water supplies are generally dependent on the GW resources (Hoque, et al., 2007; Konikow \& Kendy, 2005; Famiglietti, et al., 2011). Water used by irrigated crops (i.e., crop water demand) and irrigation water demand (including evaporative and percolation losses during transport and application) are responsible for about $70 \%$ of the global water withdrawal (Wada, et al., 2012). However, overexploitation of this resource may lead to constant GW deplition which may have devastating effects on natural streamflow, GW fed wetlands and related ecosystem (Wada, et al., 2010). In spite of these alarming situations, GW resources are often poorly monitored, that's why a consistent picture of their availability is difficult to figure out and sometimes impossible to construct. Moreover, water withdrawals from pumping wells are often unrestricted and unmonitored. Therefore, development and management of this useful resource is an important subject matter in the field of modern hydrogeology (Famiglietti, et al., 2011; Hoque, et al., 2007). By integrated distributed hydrogelogical model we can fulfill the demand of assessing sustainablility of existing GW supply and supplementary use of surfacewater. However it also serves as a useful tool to simulate recharge mechanism, flow characteristics and potential head distributions of GW system within the pre-defined hydrogeological boundary (Sinha, 2005).

$\mathrm{GW}$ is the main source of irrigation in the northwestern Districts of Bangladesh. About $75 \%$ water for irrigation in the region comes from GW (Shahid \& Hazarika, 2010). In order to achieve sustainable agricultural growth and to maintain ecological balance, the Barind Integrated Area Development Project (BIADP) under the Barind Multipurpose Development Authority (BMDA) was launched during late eighties of the last century in Chapai- Nawabganj, Naogaon and Rajshahi districts which include 25 Upazilla (sub-district) in the 'Barind area' at the northwestern part of Bangladesh. GW has been the source of irrigation in these areas, with exploitation through Deep Tubewells (DTWs) and Shallow Tubewells (STWs) (Jahan, et al., 2010). The country's largest GW-fed irrigation project, Barind irrigation project is located in this region. But in this part of Bangladesh GW depletion problem is severe because this part is free from seasonal flooding. Only source of recharging of GW aquifer in this area is rainfall, but rainfall is also lowest here among the country (Rahman \& 
Mahbub, 2012; Adhikary, et al., 2013). In this situation, a suitable framework for appropriate assessment and development of GW resources is essential. In this study, existing hydrogeological framework and available GW resources in Bhawaniganj Pourashava under Rajshahi district in Bangladesh have been investigated. Although domestic and irrigation activities in Bhawaniganj Pourashava is largely dependent on GW, currently there is no sufficient management plan in action and consequently uncontrolled GW exploitation is taking place. Lack of proper understanding about the GW system dynamics in terms of resource utilization, is one of the key limitations towards successful management of this valuable resource. Therefore, the present study has been undertaken for quantifying available $\mathrm{GW}$ resource in relation to natural GW recharge and withdrawal options.

\subsection{Location}

\section{The Study Area: Bhawaniganj Pourashava In Bangladesh}

For the GW modelling of Bhawaniganj Pourashava a larger study area has been considered to avoid the boundary influence in model computation and also water shed catchment. For hydrogeological study and GW resource assessment, specific emphasis has been given for the Pourashava area (Bhawaniganj Pourashava) and its vicinity at least the area of concerned Upazila. This area is defined as selection area in this report.

Bhawaniganj Pourashava is situated in Baghmara Upazila under Rajshahi district. The area of the Pourashava is about $11.78 \mathrm{sq}$. km. The model area is around 7,607 $\mathrm{Km}^{2}$. The model area is bounded by Indian Territory on the West and North, Ganges River on the South, and thana boundary of Badalgachi-NaogaonRaninagar and part of the L-Nagor River on the east. The model area spreads over 25 Upazilas of Rajshahi, Nawabganj and Naogaon districts. The study area is depicted in Figure 1.

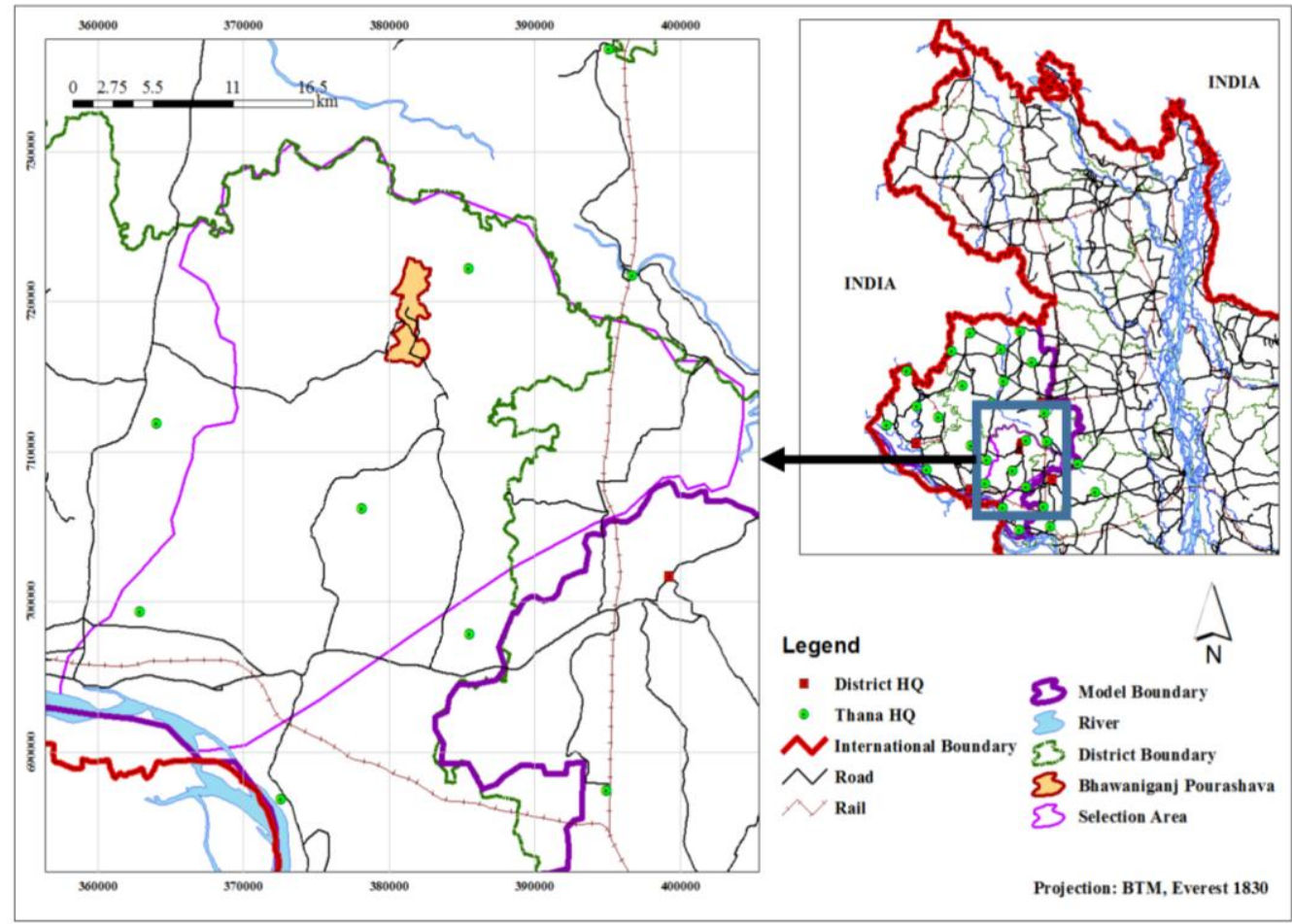

Figure 1: Location of Bhawaniganj Pourashava

\subsection{Climate}

The study area experiences a tropical humid monsoon climate. In summer the mean maximum temperature is well above $35^{\circ} \mathrm{C}$ whereas in winter the mean minimum temperature is below $10^{\circ} \mathrm{C}$. The cool weather begins in October and continues up to the end of March. The early summer is dry, with scorching winds, but the rainy season is quite wet with a range of $1800 \mathrm{~mm}$ to $2000 \mathrm{~mm}$ rainfall. Almost $80 \%$ of the rainfall occurs during June to October. The relative humidity in the study area varies from $46 \%$ to $83 \%$.

\subsection{Topography}

A well-prepared Digital Elevation Model (DEM) is essential for visualizing the floodplain topography and for accurate modelling. A DEM of $300 \mathrm{~m}$ resolution has been developed to define the topography of the study area and used in the model. Topographic data for the study area has been extracted from the topographic database developed by FAP-19 based on irrigation planning maps available at IWM. Roads alignment and 
homestead coverage also have been collected from Roads and Highway Department (RHD) and Local Government Engineering Department (LGED). Utilizing these topographic data, road alignment and homestead coverage, a DEM of $300 \mathrm{~m}$ resolution has been developed to define the topography of the study area. Elevation of the model area varies from 9.0 mPWD to $45.6 \mathrm{mPWD}$ whereas for the selection area it varies from 9.5 mPWD to $21 \mathrm{mPWD}$. The DEM of the selection area is shown in Figure 2. Land elevation of Bhawaniganj Pourashava is between $13.0 \mathrm{mPWD}$ to $15.0 \mathrm{mPWD}$.

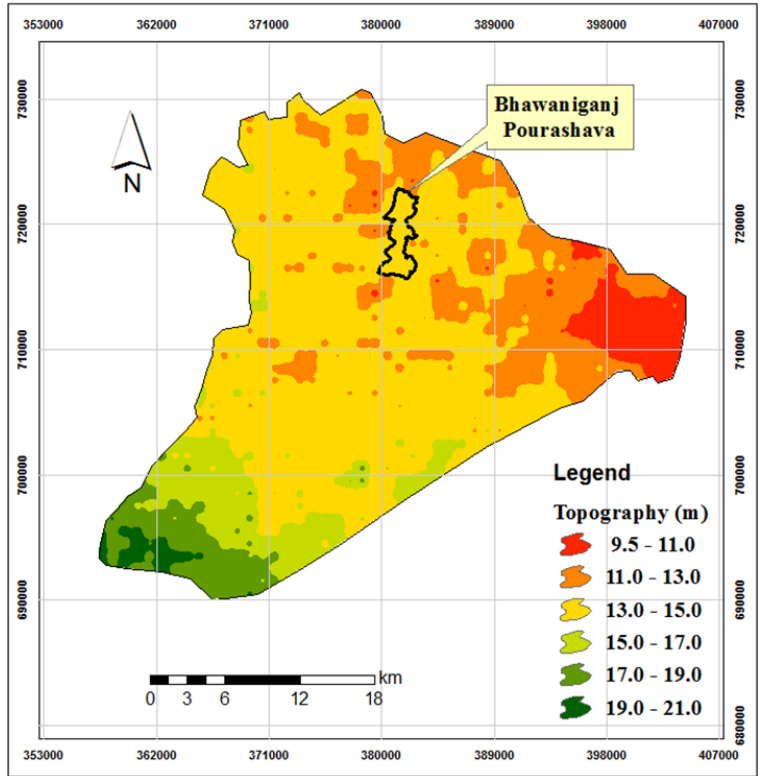

Figure 2: Digital Elevation Model (DEM) of the selection area

\subsection{Geology}

The most significance to hydrograph analysis are the thickness and composition of the aquifer and the characteristics of the deposits that overly the aquifer (upper layer). With respect to the latter it is important to identify if extensive clay layers confine the aquifer. Figure 3 shows a probability lithological plot analyzing all the lithologs present in the study area. Based on the probability plot it is clearly observed that top most layer is heavy clay layer, which is followed by aquifer layers alternatively arranged within different depths separated by clay (aquitard and aquiclude layer). The probability log also indicates that a thick clay of 10-12 $\mathrm{m}$ exist in the study area and the composition of the aquifer is mainly of medium sand and coarse sand with gravel.

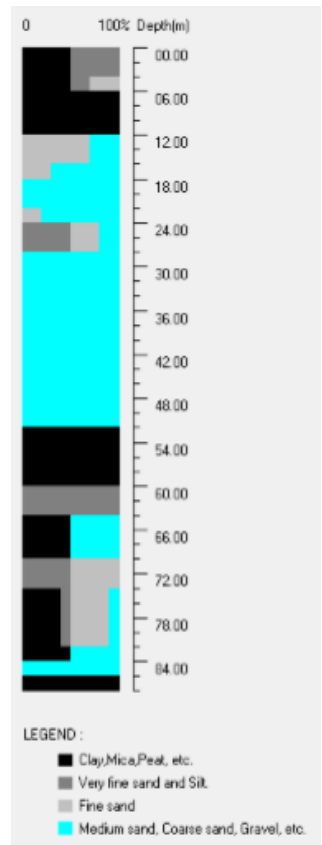

Figure 3: Probability lithological log of the study area 


\subsection{Existing Land Use Pattern}

Land use and vegetation are used in the model to calculate actual evapo-transpiration depending on the actual crops grown in the project area. Major part of the model area is agricultural land. In this study, for modelling purpose the cropping types and cropping pattern have been simplified considering the major crops that require irrigation water. A crop database for each crop, which defines leaf area index, root depth and other properties of each crop are developed based and used in the model. Crop calendar of the selection area reveals Boro, T. Aman and Sugarcane are the main crops. Spatial distribution of cropping pattern for the selection area is shown in Figure 4.

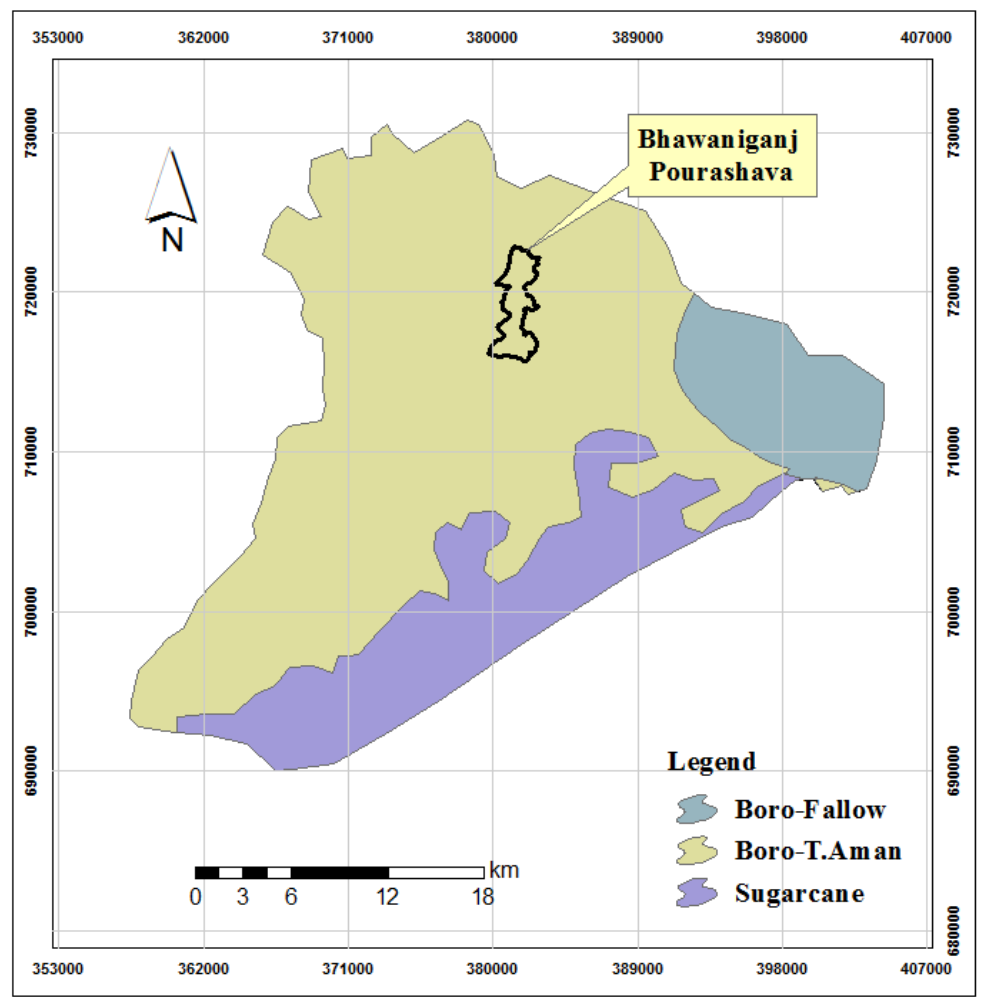

Figure 4: Spatial distribution map of land use for the selection area

\section{Data Collection And Processing}

For the purpose of GW source identification and resource assessment, huge hydrogeological and meteorological data have been collected from different organization. For hydrogeological study of the Bhawaniganj Pourashava and its surrounding area secondary data has been collected for analysis. After collecting the required data, they were assessed through necessary quality control procedure. Type of collected data and corresponding agency name are presented in Table 1.

Table 1: Secondary Data Type and Corresponding Source

\begin{tabular}{|c|c|}
\hline Data Type & Agency \\
\hline Lithological Data & $\begin{array}{l}\text { Department of Public Health Engineering (DPHE) } \\
\text { Bangladesh Water Development Board (BWDB) } \\
\text { Institute of Water Modelling (IWM) } \\
\text { Barind Multipurpose Development Authority (BMDA) }\end{array}$ \\
\hline Aquifer Test Data & BWDB, DPHE \\
\hline GW Table & BWDB \\
\hline Rainfall Data & BWDB \\
\hline
\end{tabular}

\subsection{Hydro-Meteorological Data Precipitation}

Rainfall data is needed as input to the model. Eighteen (18) rainfall stations are available in and around the model area. However, the selection area for Bhawaniganj Pourashava contains six (06) rainfall stations. To account for the spatial variation in rainfall, the time series data for each station has been associated with an area. This area has been estimated by Thiessen Polygon Method. Thiessen polygons for each rainfall stations have been shown in Figure 5. 


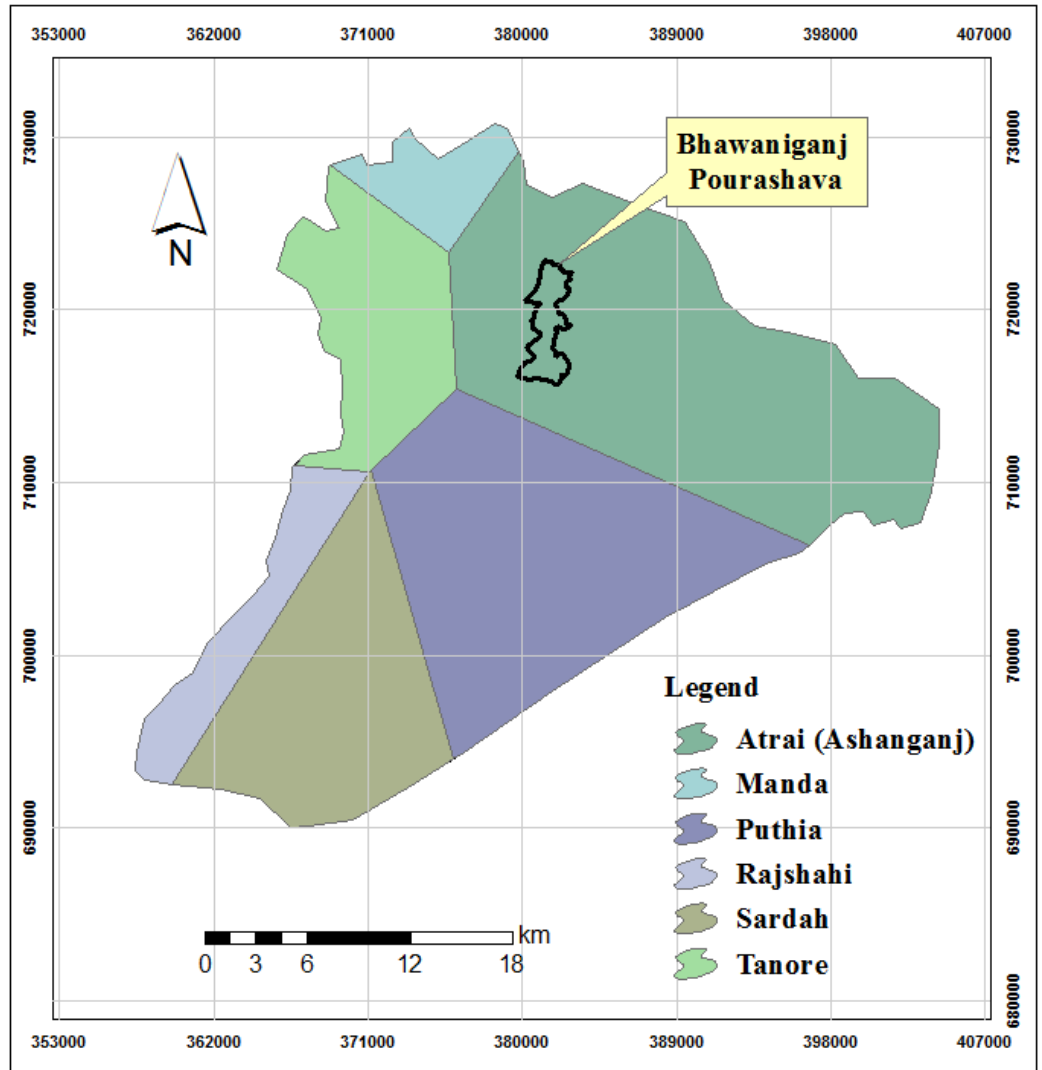

Figure 5: Thiessen Polygons for Rainfall Stations in Selection Area

\section{Evapo-transpiration}

The actual evapo-transpirations are estimated in the model on the basis of potential evapotranspiration rates, the root depths and leaf area indexes of different crops over the seasons. Model uses Kristensen and Jensen formula for calculation of actual evapotranspiration. Time series of the potential evapotranspiration are given as input to the model. Evaporation data for Rajshahi station has been used in the model.

\subsection{Model Setup}

\section{Gw Modelling And Assessment}

GW model setup involves a geometrical description and specification of physical characteristics of the hydrological system of the study area. The major components of the model setup include evapo-transpiration, unsaturated zone, saturated zone, overland flow and river systems. The approach of the model study is shown in a schematic plan as illustrated in Figure 6. 


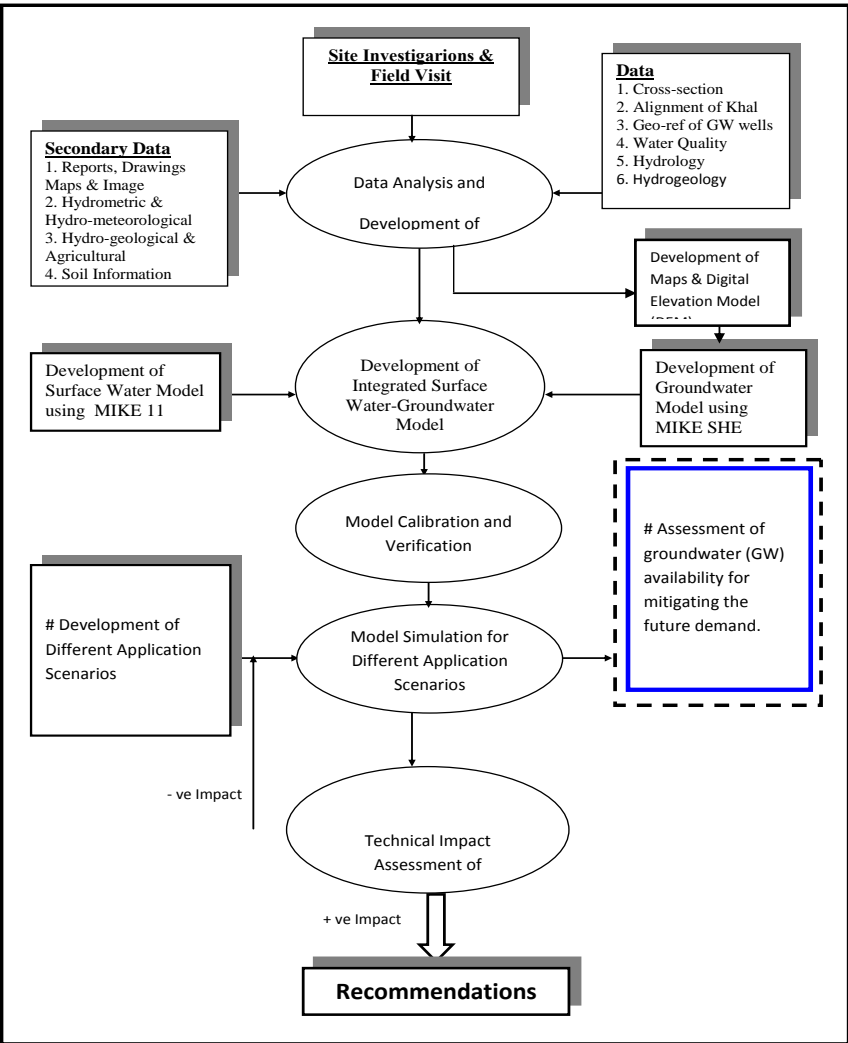

Figure 6: Schematic Plan of Modelling Activities

\section{Simulation Specification}

The default time step control and computational control parameters for overland flow (OL), unsaturated zone (UZ) and saturated zone (SZ) have been used for entire simulation period. However, simulation periods of the calibration, validation and prediction models were different and user specified.

\section{Model Domain and Grid Size}

The study area has been discretized into $1000 \mathrm{~m}$ square grids as shown in the horizontal plan of the Figure 7 . The model has 7,598 grid cells in each layer, whereas 425 grids are the boundary cells and the rest are computational cells. The grid cells are the basic units to provide all the spatial and temporal data as input and to obtain corresponding data as output.

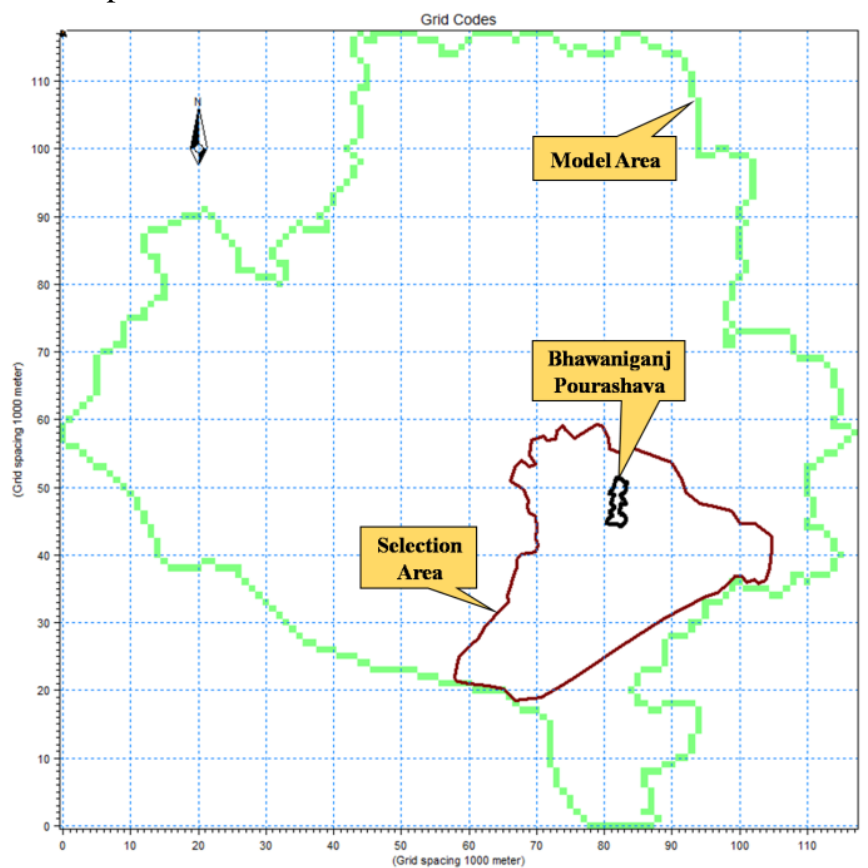

Figure 7: Model Domain with Grid 1000m 


\subsection{Coupling of GW And SW Model}

The coupling of surface water with GW model involves a number of specifications. The river reaches where the coupling will take place have been defined in river model. In the present study, all the major rivers and canals within the study area have been coupled with GW. Type of river-aquifer exchange and the flooding condition have also been defined. The exchange of flow between the saturated zone component and the river component is mainly dependent on head difference between river and aquifer and properties of riverbed material such as leakage coefficient. For river-aquifer exchange, leakage coefficients along with the hydraulic conductivity of the saturated zone are taken into account for most of the river reaches.

\subsection{Model Calibration and Model Validation \\ Model Calibration}

The purpose of model calibration is to achieve an acceptable agreement with measured data by adjusting the input parameters within acceptable range. As a coupled surface water $\mathrm{GW}$ model contains huge number of input data, the parameters to adjust during the calibration could be numerous. During the calibration it is therefore important to adjust the parameters within the acceptable range determined from field measurements, and also to minimize the number of adjusted parameters. In this study, the initial input parameters have been obtained from secondary sources. The model has been calibrated for the period 2003 to 2007 where as the model has been verified for the period of 2008 to 2009 with the existing data available from the secondary sources. In the present model, calibration has been done against groundwater level (GWL). During calibration overland leakage coefficient, vertical hydraulic conductivity, storage coefficient and river leakage coefficient have been adjusted. The sample calibration plots are given in Figure 8.

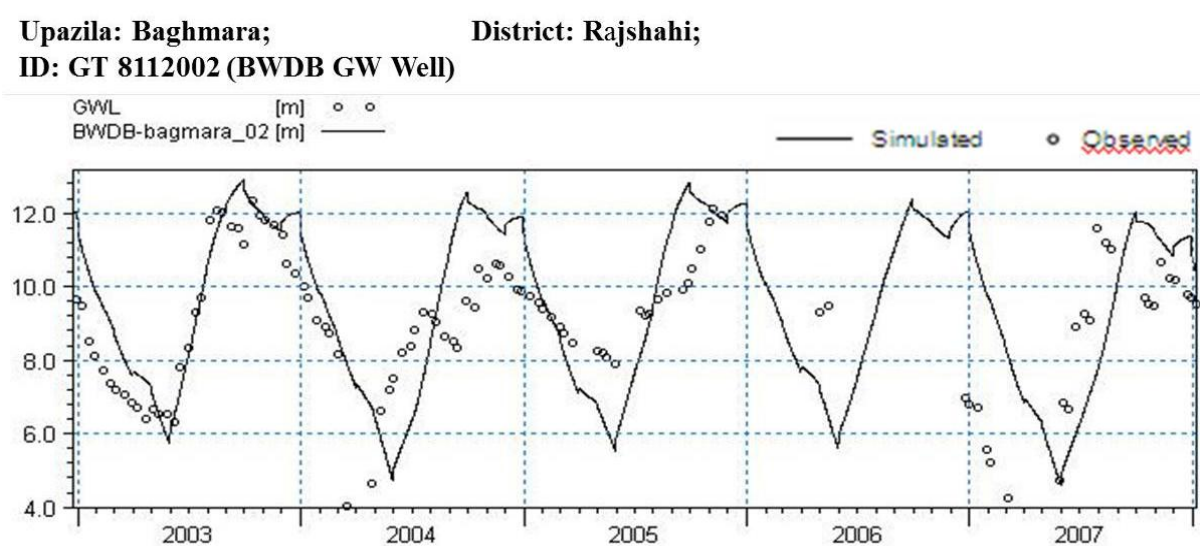

Upazila: Manda; District: Naogaon; ID: GT 6447021 (BWDB GW Well)

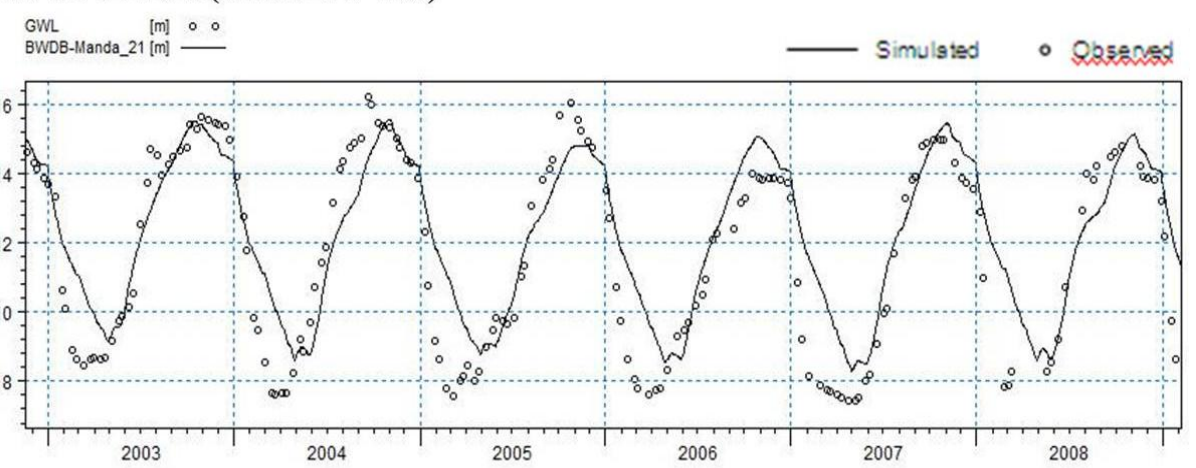

Figure 8: Sample Plots of Calibration

\section{Model Validation}

It is customary that the calibrated model should be verified outside the calibration period. In order to increase the reliability of the model, it has been validated using the data for the period of 2008 to 2009. Examples of validation results against GWL for the period 2008 to 2009 are shown in Figure 9. Overall, validation results show similar trend of GW fluctuation between observed and simulated values for the validation periods. From the results of the model validation, it could be concluded that the parameters used in the calibrated model are more or less acceptable, thus the model can be used carefully for further prediction purposes 


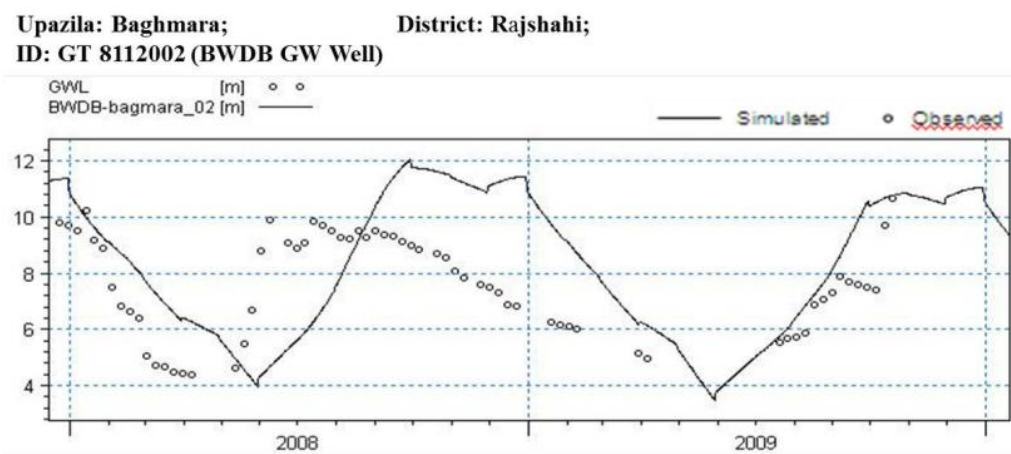
Upazila: Manda; District: Naogaon;
ID: GT 6447021 (BWDB GW Well)

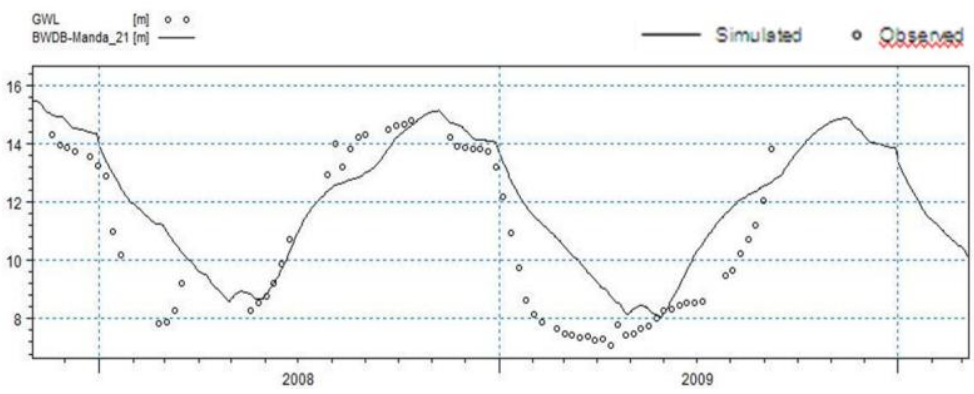

Figure 9: Sample Plots of Validation

\subsection{Selection of Design Year}

\section{Options Study And Evaluation}

For GW and surface water resource assessment, rainfall data were analyzed to estimate the rainfall event for different return period. In selecting design event, most weight was given for $80 \%$ dependable annual rainfall, because this is considered generally significant for domestic requirement considerations. Accordingly, analysis was concentrated on rainfall event for 5-year return period and corresponding design year was determined. Observed annual rainfall for 18 stations falls in and around the study area, out of these all stations have been considered for the statistical analysis for a period of 30 years (1980-2009). According to the recommendation of FAP-25 study, data has been fitted to 3-parameter Log Normal distribution to find out the average and extreme dry year. The statistical software HYMOS 4.0 has been used for this purpose.

For analysis, an arbitrary value higher than the annual total rainfall has been assumed. In the present case it is assumed to be $10,000 \mathrm{~mm}$. The yearly rainfalls have been deducted from this value and a data set has been generated. Then data has been fitted to 3-parameter Log Normal distribution to find out the average and extreme dry year. The outputs are deducted from the assumed value of $10,000 \mathrm{~mm}$ to get the annual rainfalls with different return periods. The tabular values of 18 stations in Table 2.It is quite obvious that due to the randomness of rainfall events, all rainfall events for each station will not represent a unique design year and it is necessary to select a design year on the basis of stations, those represent a unique design year. It is seen from Table 2.3 that 7 stations namely Bholahat, Mahadebpur, Nachole, Puthia, Nithpur, Rohanpur and Sapahar represent the year 2008 as 5 yrs return-period event. As such, 2008 has been selected as the design year.

Table 2: Annual average rainfall for different return periods (in $\mathrm{mm}$ )

\begin{tabular}{|l|l|l|l|l|}
\hline Station & 2 yrs $(\mathrm{mm})$ & Matching Year & 5 yrs $(\mathrm{mm})$ & Matching Year \\
\hline Atrai & 1554.4 & 2005 & 1190.9 & 2010 \\
\hline Badalgachi & 1703.4 & 2010 & 1410.8 & 2009 \\
\hline Bholahat & 1542.6 & 2010 & 1150.4 & 2008 \\
\hline Godagari & 1374.2 & 2008 & 1146.4 & 2006 \\
\hline Mahadebpur & 1677.4 & 1999 & 1403.2 & 2008 \\
\hline Manda & 1463.1 & 1999 & 1195.1 & 2009 \\
\hline Nachole & 1510.8 & 2000 & 1161 & 2008 \\
\hline Njirpur & 1550.1 & 2003 & 1154.4 & 2009 \\
\hline Naogaon & 1598.6 & 2007 & 1349.2 & 2009 \\
\hline Nawabganj & 1351.4 & 2008 & 1067.6 & 2010 \\
\hline Nithpur & 1572.1 & 2008 & 1232.3 & 2008 \\
\hline Puthia & 1570.2 & 2007 & 1256.3 & 2008 \\
\hline Rajshahi & 1452.5 & 2003 & 1162.5 & 2005 \\
\hline Rohanpur & 1427.8 & 2009 & 1169.4 & 2008 \\
\hline
\end{tabular}


Groundwater Resource Assessment: in the Context of Bhawaniganj Pourashava

\begin{tabular}{|l|l|l|l|l|}
\hline Sapahar & 1537.3 & 2006 & 1250.3 & 2008 \\
\hline Sardah & 1505.3 & 2003 & 1165.9 & 2010 \\
\hline Shibganj & 1472.4 & 2008 & 1154.2 & 2010 \\
\hline Tanore & 1515.6 & 2002 & 1201.7 & 2007 \\
\hline
\end{tabular}

\subsection{Technical Evaluation of Options}

Results of the option simulations are analyzed, presented and compared with the base condition in the following manner:

$>$ GWL hydrographs

$>$ Spatial distribution map of depth to GW table

Hydrograph of GWL under different options indicate the state of GWL with respect to time and depth to ground surface.

\section{Option 0: Base Condition i.e. Existing Situation}

The base condition includes design year hydrological situation and other existing situations that prevail in the field. The main purpose of the base option is to understand the present state of project under design year in terms of volume of water presently being used, whether it crosses the potential recharge of the aquifer, present state of GW table, crop coverage and scope for further expansion considering the availability of water. Crop coverage under different crops of existing condition with domestic and industrial demand has been considered in base option.

\section{Spatial Distribution Map of Depth to GW Table}

Hydrographs of simulated GW tables were obtained at some pre-selected locations, which show that the maximum and minimum depth to GW table occurs at the end of April and end of October respectively. Hydrographs of observed GW table also support the above findings. Based on these findings, spatial distribution maps of maximum and minimum depth to GW tables were prepared for 01.05.2008 and 01.11.2008 (Figure 10 \& 11) to see the effect of pumping and also to see whether $\mathrm{GW}$ table of 2008 regains to its original positions. It can be seen from the Figure 10 that maximum depth to phreatic surface (DTPS) remains in the range between (-) $0.0 \mathrm{~m}$ to (-) $17.5 \mathrm{~m}$ in the selection area. It is observed from Figure 11 that during the peak time, GW table remains in the range between (-) $0.0 \mathrm{~m}$ to (-) $7.3 \mathrm{~m}$ in the selection area. Figure 12 depicts contours of DTPS on May 01, 2008 and November 01, 2008 within Bhawaniganj Pourashava area.

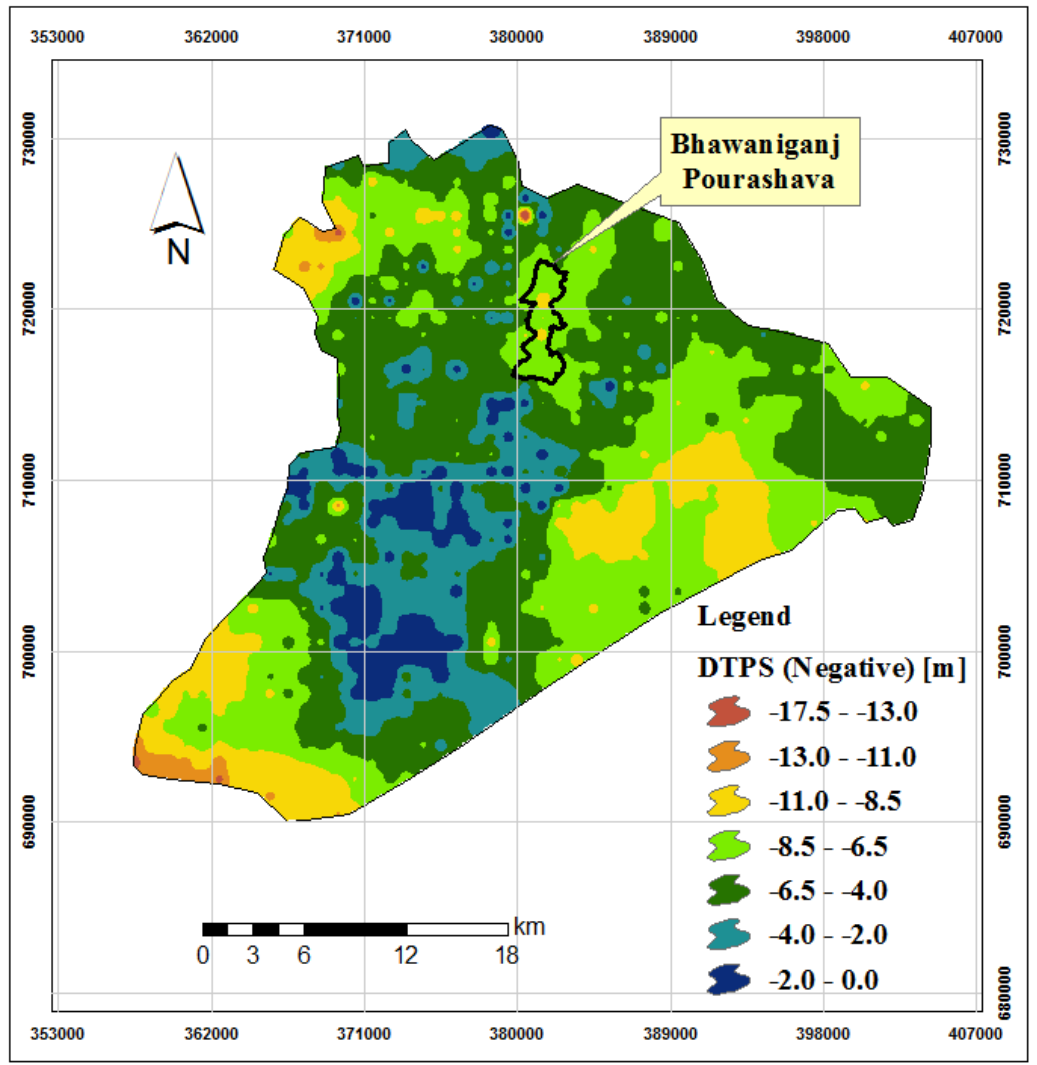

Figure 10: Maximum Depth to Phreatic Surface on May 01, 2008 for Option 0 


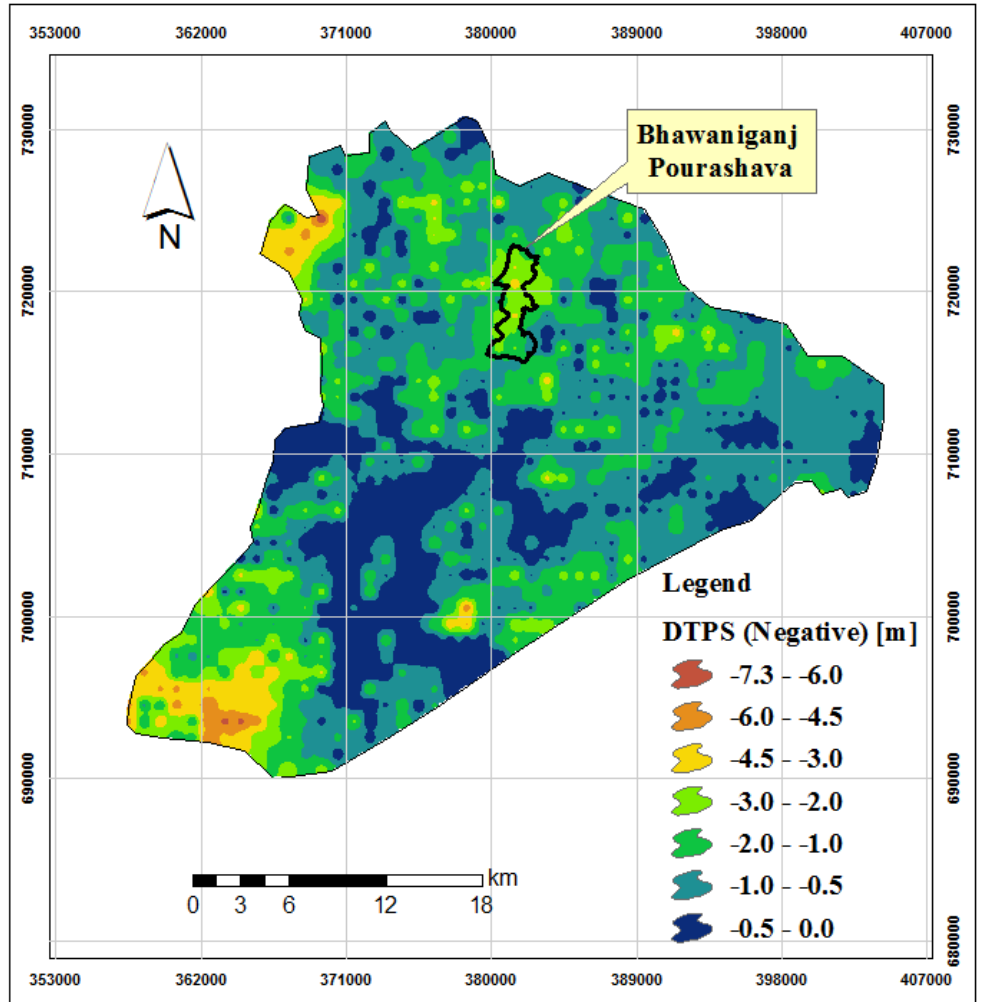

Figure 11: Minimum Depth to Phreatic Surface on November 01, 2008 for Option 0
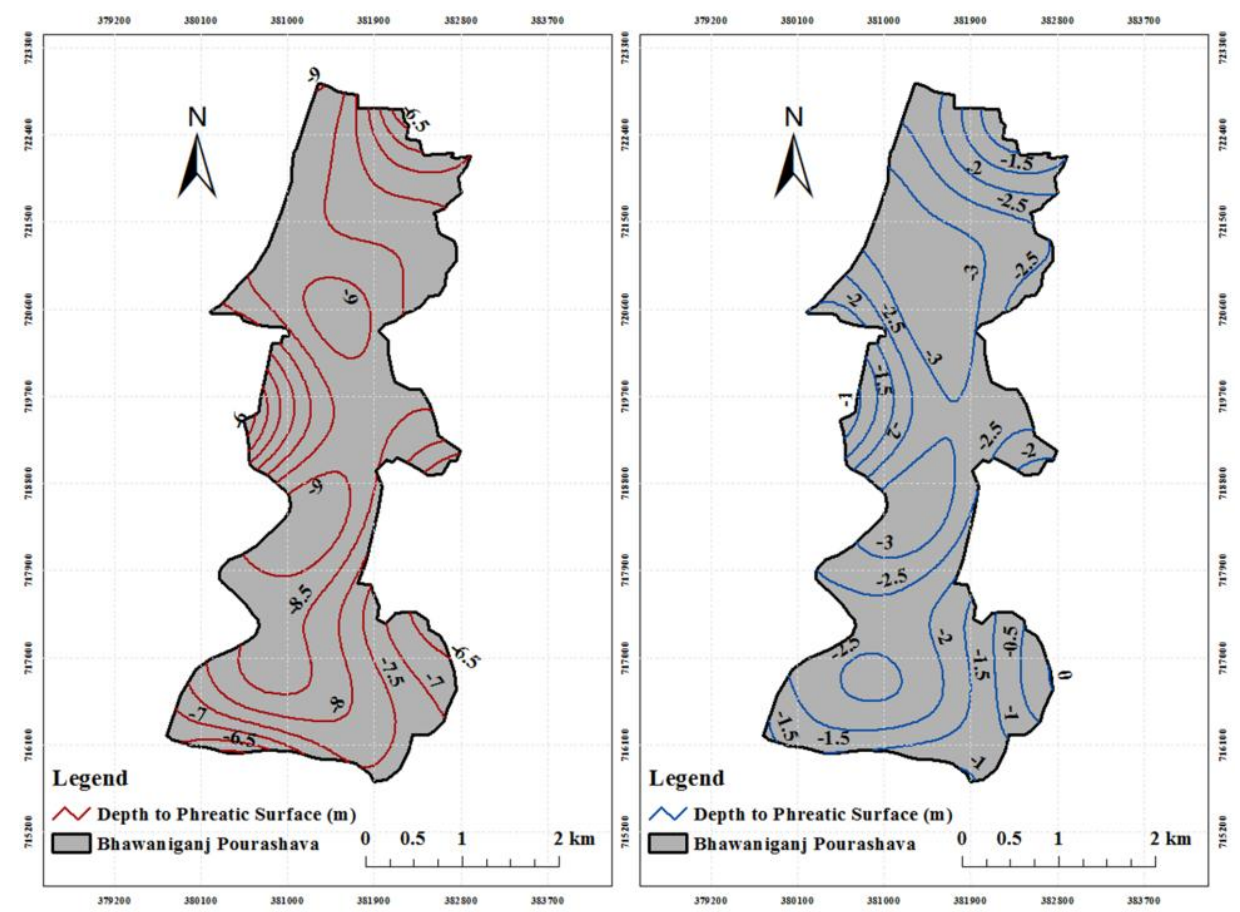

Figure 12: Contour Map of Depth to Phreatic Surface for Bhawaniganj Pourashava on May 01, 2008 (at left) and November 01, 2008 (at right) for Base Condition.

\section{Option I: Long term Simulation}

Option I is the future development option, which mainly includes future abstraction of water from GW to meet the domestic and industrial demand for Bhawaniganj Pourashava. The purpose of this option is to assess the impact of future development on the present state of GW. For simulating this option, four (04) tubewells are proposed. The location of pumps is shown in Figure 13. The screen of the pump is set between the depths of 35 $\mathrm{m}$ to $45 \mathrm{~m}$ at the lower shallow aquifer with a capacity 0.50 cusec. 


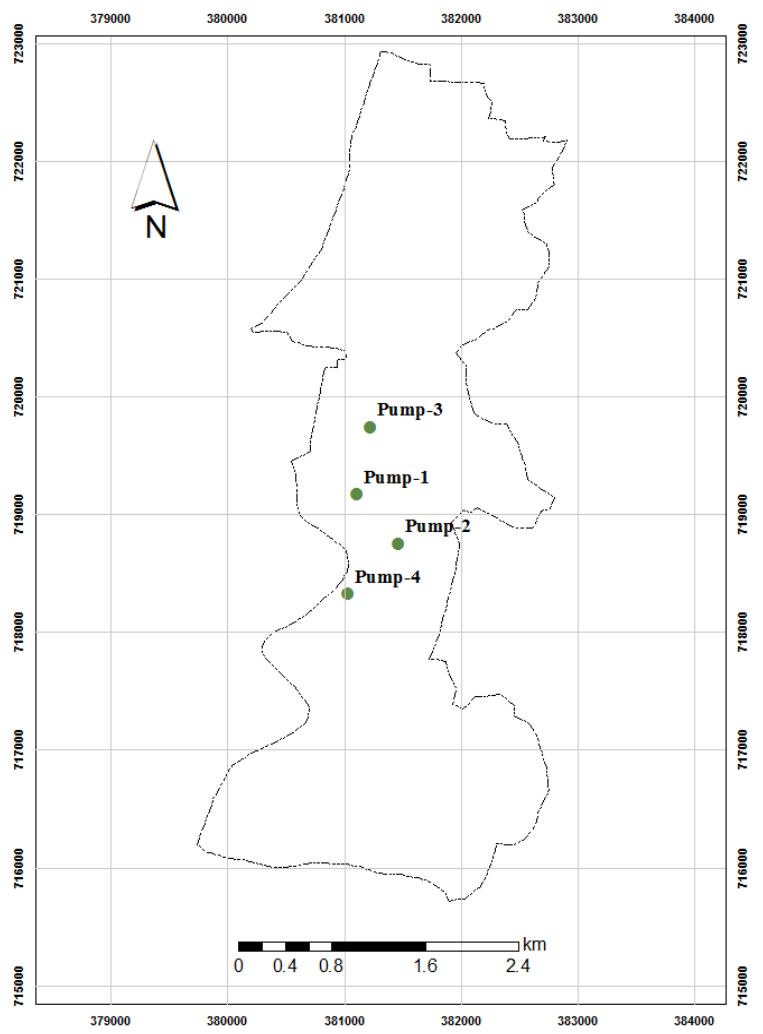

Figure 13: Location of Proposed Pump

\section{Hydrograph Analysis}

After long term simulation considering the future domestic and industrial demand with proposed four (04) production wells of capacity mentioned in the above Table 2.4, sample plots of GWL hydrographs are shown in Figure 14. From the hydrographs for four (04) proposed production wells, it reveals that, GWL will drop down maximum $1.0 \mathrm{~m}$ due to future abstraction compared to the GWL of base condition.
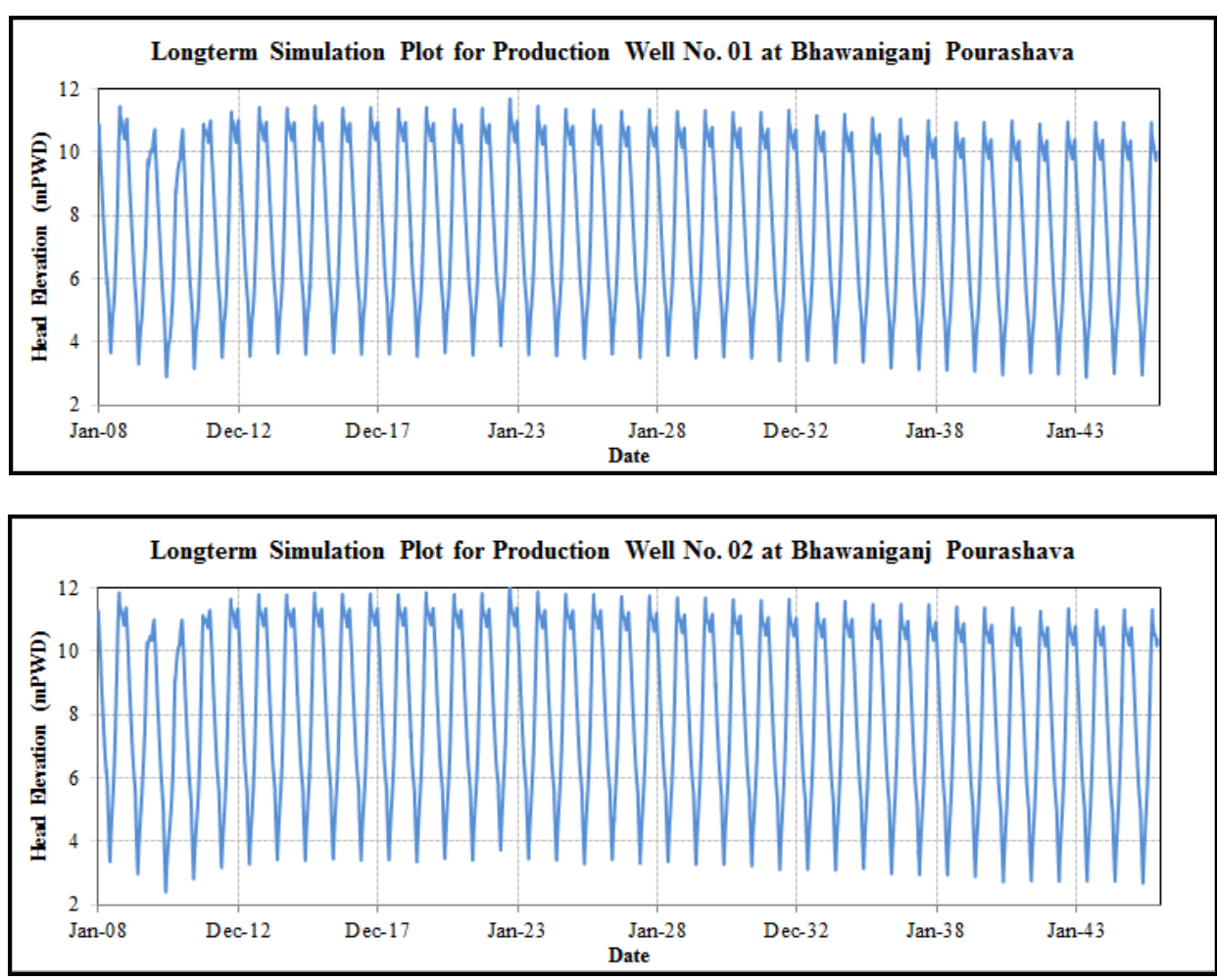

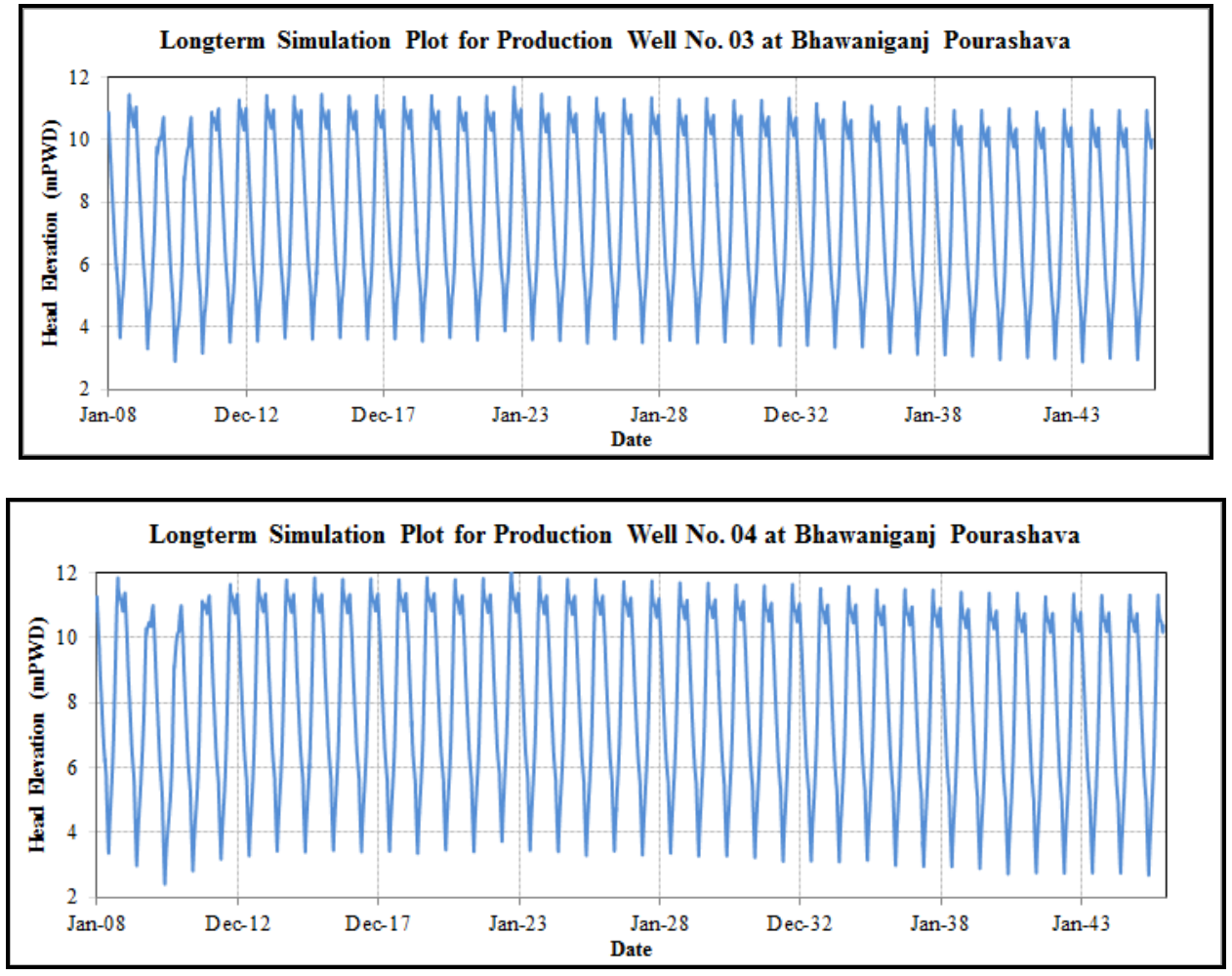

Figure 14: GWL Hydrograph for Long Term Simulation under Option 1

\section{Spatial Distribution Map of Depth to GW Table}

The head elevation in the lower shallow aquifer due to future pumping in 2045 is presented in Figure 14 which reveals that the minimum elevation in GWL occurs with a value of $3.0 \mathrm{mPWD}$. The change in GWL due to the proposed abstraction in 2045 is also calculated by subtracting the head elevation in 2045 from head elevation of base conditions. A map of change in GWL contour in 2045 for Bhawaniganj Pourashava is shown in Figure 15.

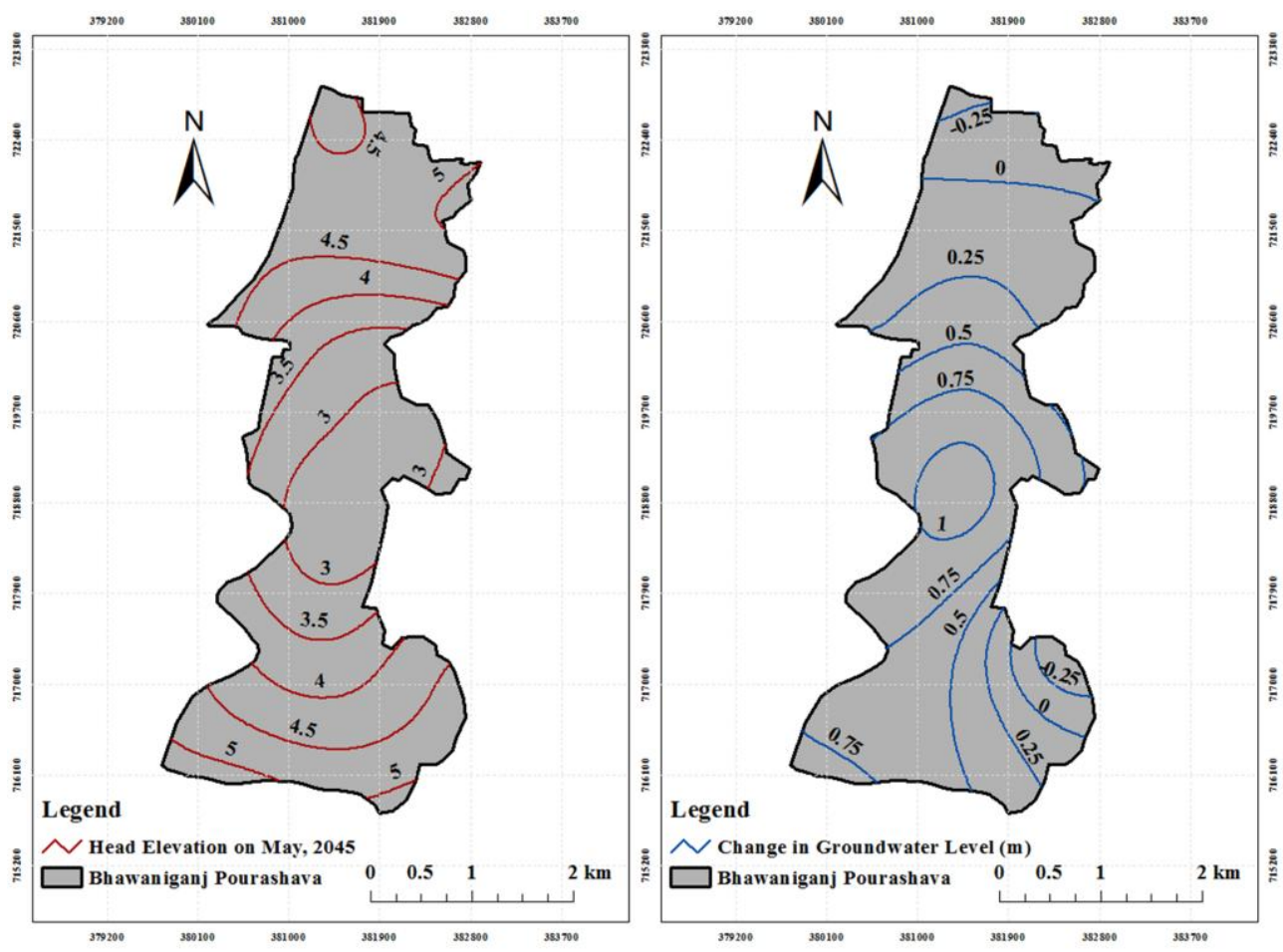

Figure 15: Map showing GWL in 2045 after proposed Abstraction (Left) and Map showing difference of GWL of 2008 and 2045 considering respective Abstraction (Right) 


\subsection{GW Resource Assessment}

By analyzing the available borelog data it is observed that there exists deeper aquifer in the vicinity of Bhawaniganj Pourashava. As a result, the availability of water resources at the lower shallow aquifer is assessed based on the Water Balance study for the individual layers. To calculate the water balance, the lower shallow aquifer is considered as confined aquifer in nature which means there is no connection with the upper layer. A trial and error method is applied to find out the maximum abstraction without any negative changes of storage for the said aquifer. Firstly, small amount of abstraction is imposed for the target aquifer and gradually increases to reach the negative change in storage by inspecting the water balance of the model. The maximum abstraction which does not have negative change in storage is considered as the allowable limit of abstraction. The allowable limit of abstraction for the target aquifer is calculated based on the final water balance as shown in Figure 16.

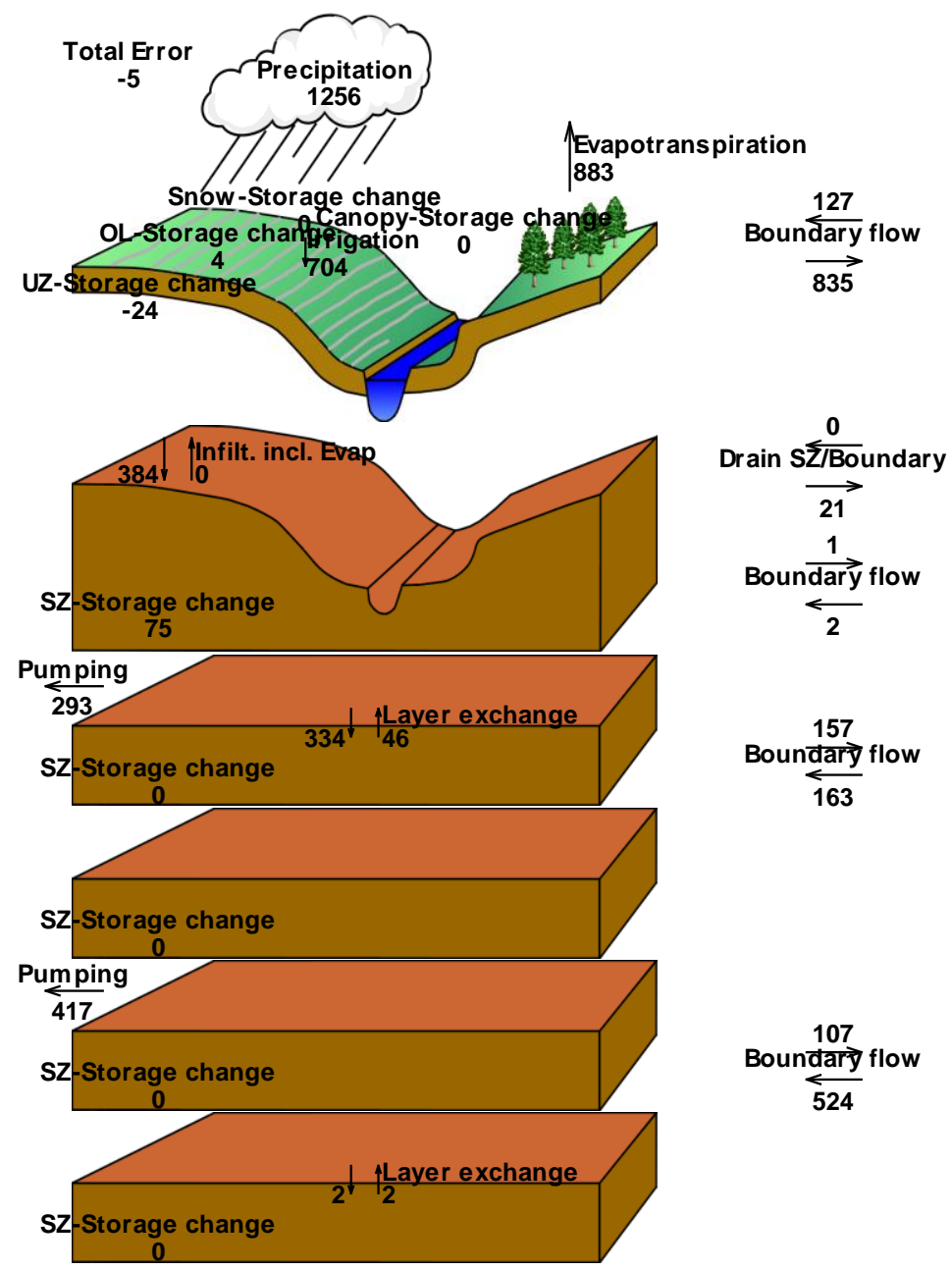

Figure 16: Water Balance (in mm) for Base Condition for January 01, 2008 - December 31, 2008

The net recharge for the lower shallow aquifer is calculated as follows:

The net recharge $=524 \mathrm{~mm}$ (for inflow) $-107 \mathrm{~mm}$ (for outflow) $=417 \mathrm{~mm}$. For this amount of GW recharge, the corresponding allowable limit of abstraction volume is found to be $4.19 \mathrm{Mm}^{3}$ per annum.

\section{Conclusion}

From the hydrographs and water balance study it can be concluded that a total four (04) production wells of 0.5 cusec capacity are required to meet the water demand of $1.60 \mathrm{Mm}^{3}$ for the Bhawaniganj Pourashava for the year 2040. The allowable limit of abstraction for the Pourashava at lower shallow aquifer is found to be $4.19 \mathrm{Mm}^{3}$ per annum. Hence it can be concluded that the allowable limit of abstraction is higher than the required water demand of $1.60 \mathrm{Mm}^{3}$ for the year 2040 . While conducting this study it is appeared that the GW model is developed on the basis of available limited secondary data. Model reliability increase with increase of number of reliable data. More GW data in and around the Pourashava needs to be regularly recorded and monitored. Updating of this GW model with more collected data in future will be very useful for evaluating a more accurate scenario. 


\section{Acknowledgements}

The authors wish to express their deep acknowledgment to BWDB, WARPO, BADC and IWM for providing valuable data supports, technical supports and suggestions during the completion of complete the study.

\section{Reference}

[1]. Adhikary, S.K., Das, S.K., Saha, G.C. and Chaki, T., 2013, December. Groundwater Drought Assessment for Barind Irrigation Project in Northwestern Bangladesh. In 20th International Congress on Modelling and Simulation, Adelaide, Australia (pp. 1-6).

[2]. Famiglietti, J.S., Lo, M., Ho, S.L., Bethune, J., Anderson, K.J., Syed, T.H., Swenson, S.C., De Linage, C.R. and Rodell, M., 2011. Satellites measure recent rates of groundwater depletion in California's Central Valley. Geophysical Research Letters, 38(3).

[3]. Hoque, M. A., Hoque, M. M. \& Ahmed, K. M., 2007. Declining GWL and aquifer dewatering in Dhaka metropolitan area, Bangladesh: causes and quantification. Hydrogeology Journal, 15(8), pp. 1523-1534

[4]. Jahan, C. S., Mazumder, Q. H., Islam, A. T. M. M. \& Adham, M. I., 2010. Impact of Irrigation in Barind Area, NW Bangladesh An Evaluation Based on the Meteorological Parameters and Fluctuation Trend in Groundwater Table. Journal of the Geological Society of India, 76(2), pp. 134-142.

[5]. Konikow, L. F. \& Kendy, E., 2005. Groundwater depletion: A global problem. Hydrogeology Journal, 13(1), pp. 317-320.

[6]. Rahman, M. M. \& Mahbub, A. Q. M., 2012. Groundwater Depletion with Expansion of Irrigation in Barind Tract: A Case Study of Tanore Upazila. Journal of Water Resource and Protection, 4(08), p. 567.

[7]. Shahid, S. \& Hazarika, M. K., 2010. Groundwater drought in the northwestern districts of Bangladesh. Water Resource Management, 24(10), pp. 1989-2006.

[8]. Sinha, A. K., 2005. Groundwater Modelling-An Emerging Tool for Groundwater Resource Management. Numerical Simulation of Groundwater Flow and Solute Transport, edited by Elango L. Allied Publishers Pvt. Ltd., Chennai, pp. 15-28.

[9]. Wada, Y., Beek, L. \& Bierkens, M. F., 2012. Nonsustainable groundwater sustaining irrigation: A global assessment. Water Resources Research, 48(6)

[10]. Wada, Y., van Beek, L.P., van Kempen, C.M., Reckman, J.W., Vasak, S. and Bierkens, M.F., 2010. Global depletion of groundwater resources. Geophysical research letters, 37(20). 